The International Journal of Indian Psychology: Volume: 01 | Issue: 04 | ISSN 2348-5396

\title{
Mental Health and Marital Adjustment among Working and Non Working Women
}

\author{
Sonalba G. Parmar*
}

\begin{abstract}
The study was conducted to assess the status of mental health and marital adjustment of the working and non working women. The random sample consisted of 30 working women and 30 non working women selected. Mental Health Inventory by Dr. A.K. Shreevastav and Dr. Jagdish and marital adjustment inventory by P. Kumar and K. Rohatgi. Here t' test was applied to check the significance of mental health and marital adjustment in working and non working women.
\end{abstract}

The result shows that there is a significant difference between working and non working women in mental health and marital adjustment so the Hypothesis is not accepted.

\section{INTRODUCTION}

In order to find happiness, modern human beings are trying their level best in more ways than one. Human beings have to face many challenges and problems in life and nowadays and everyone has to be mentally as well as physically prepared for such situations. This kind of strength is required in order to cope with modern difficult circumstances.

$21^{\text {st }}$ century has been a new Dawn for women in terms of progress as they are matching every step with men. They have to always be ahead of the situation within the society. Important junctures in everyone's life (especially women) are birth, marriage, occupation and death. Talking about marriage as an institution, we can say that it changes the life of any individual, especially women, dramatically. They have to go through plenty of changes.

Women after marriage have to carry the burden of dual responsibilities. One is to take care of the biological parents and in addition to that they also have to equally take care of their parents-in-law. Women have to go through a lot of mental struggle in order to be a balancing force and solving all the domestic problems with extreme maturity.

A woman who is able to maintain her mental calm in all the situations can really be successful in all the phases of life. Problems with regard to modern society have multiplied courtesy which, she has to go through a lot of mental stress irrespective of whether she is a working or a non working woman.

*Assistant Professor, Nandkunvarba Mahila College, Maharaja Krishnakumarsihnji Bhavnagar University. Gujarat 


\section{The International Journal of Indian Psychology: Volume: 01 | Issue: 04 | ISSN 2348-5396}

Present research therefore makes an attempt toward the focusing upon the mental health and marital peace of both working and non working women.

The sense of one's identity or self is an important dimension of individual's personality giving each one of us unique individuality. Women and depression is holding a relationship of much interest over the last two decades. As more and more women enter the work force, they are increasingly exposed not only of the same work environment as men, but also to pressure created by multiple roles and conflicting expectations (Nelson and Burke 2000; Chang 2000). It has long been observed that women are about twice as likely to become clinically depressed (to have dysthmia or unipolar depression) as are men. These differences occur in most countries around the world. (Nolen - Hoeksemo and Girgus, 1994; Whilelm and Roy, 2003; Ge and Conger, 2003).

Depressions are normal features of our lives. Modernity brought women education in its wake and she changed the arena of activity. She stepped out of the house and joined service like man. Now she got admiration, equality and opportunity. But the euphoria was ephemeral as she was supposed to take to this job as an additional responsibility. She not expected to shrink household work. This brought problems like strain and depression. (Pillai and Sen) (1998).

Women by their very nature are expressive emotional and sensitive. Physiological social and cultural background of women probably plays a key role in mending a women's attitude and natures towards the external relation we know that women are generally more at risk to develop psychological disorder and depression in particular.

Health is a process, which evolves on environmental and historical lines towards farther objectives. Thus locals is always in a given control depends upon existing conditions which are themselves related to the changes that take place in the environment. Internal organic factors, their homeostatic state and interaction with the environmental life of an individual would be very simple if all the needs were automatically fulfilled. But it is a fact that there are many obstacles both environmental and personal that mental interface and such obstacles place an individual in a stressful situation.

In a book entitled mental hygiene in public health P. V. Lewkan has written that mentally healthy individual is one who is herself satisfied, lives peacefully with his neighbours, makes

healthy citizens of his children and even after performing these fundamentals duties has enough energy left to do something of benefit to society? Possessing mental health, an individual can 


\section{The International Journal of Indian Psychology: Volume: 01 | Issue: 04 | ISSN 2348-5396}

adjust properly to his environment, and can make the best effort for his own, his family's and his society's progress and betterment. The chief characteristic of mental health is adjustment. The greater the degree of successful adjustment the greater will be the mental health of the individual. Lesser mental health will lead to less adjustment and greater conflict.

With regard to marital adjustment we may say that it is the state in which there is an overall feeling in husband and wife of happiness and satisfaction with their marriage. Most people marry with bundles of expectations, some of them are realistic but most of them are unrealistic to the core. This kind of situation makes marriage a very complex affair. 'Marital adjustment' as a phrase itself is questionable because adjustment is supposed to be a temporary thing whereas marriage is a life time commitment. One should not have to even think of adjusting as it only aggravates the problems. Marriage as a decision calls for extreme maturity. If taken under severe pressure, it may lead to disastrous situations especially for women. It actually works and grows as undetected cancer that kills slowly, softly but surely.

Perhaps half of the adults suffering from severe stress blame the deteriorating relationships on their spouse. Looking at the growing rate of divorces, court cases for alimony, physical abuses and single parents; it does seem as if handling a relationship can be a tricky and often taxing issue. The possible causes can be endless. More often than not, stress arising from marital relationships is manifested in chronic disorders such as depression, insomnia and hypertension. Since a relationship depends on the nature of the persons involved, it helps to seek the middle path when the inherent individual differences surface. It often helps to change one's attitude, go for counseling or talk openly with your spouse about problems facing your relationship

\section{Methodology}

\section{OBJECTIVES:}

1. The study of mental health among working and non working women.

2. The study of marital adjustment among working and non working women.

3. The study of mental health and marital adjustment among working and non working women.

\section{HYPOTHESES:}

1. There is no significant difference between working and non working women in mental health.

2. There is no significant difference between working and non working women in marital adjustment. 
The International Journal of Indian Psychology: Volume: 01 | Issue: 04 | ISSN 2348-5396

3. There is no significant difference between working and non working women in mental health and marital adjustment.

\section{SAMPLE:}

The sample was stratified of married women from Bhavnagar city among them 30 from working women and from 30 non working women.

\section{VARIABLE:}

In depended variable.

1. Working women

2. Non working women

\section{DEPENDED VARIABLE:}

1. The gets on marital health among working and non working women.

2. The gets on marital adjustment among working and non working women.

\section{TOOLS:}

1. Individual Information sheet.

2. Mental health and marital adjustment inventory

The mental health gust constructed and standardized by A.K. Shreevastav and Dr. Jagdish used from the study. This scale reliability $\mathbf{0 . 7 3}$ and validity of 0.54 The marital adjustment guest constructed and standardized by P. Kumar and K.Rohatgi used from the study. This scale reliability of $\mathbf{0 . 7 1}$ and a validity of $\mathbf{0 . 8 4}$.

\section{STATISTICAL ANALYSIS}

In this study t' test was conducted as a statistical technique to find out the aim.

\section{RESULT AND DISCUSSION:}

' $\mathrm{t}$ ' ratio of the mental health between working and non working women.

\section{$\underline{\text { Table-1 }}$}

\begin{tabular}{|l|l|l|l|l|l|}
\hline Variable & $\mathbf{N}$ & $\mathbf{M}$ & SD & 't' value & Level of Significance \\
\cline { 1 - 4 } Working women & 30 & 184.23 & 13.45 & & \multirow{2}{*}{2.13} \\
$\begin{array}{l}\text { Non working } \\
\text { women }\end{array}$ & 30 & 175.73 & 17.36 & 0.05 \\
**p $<\mathbf{0 . 0 5}$ & & & & \\
\hline
\end{tabular}


The International Journal of Indian Psychology: Volume: 01 | Issue: 04 | ISSN 2348-5396

\section{Table-2}

' $\mathrm{t}$ ' ratio of the marital adjustment between working and non working women.

\begin{tabular}{|l|l|l|l|l|l|}
\hline Variable & N & M & SD & 't' value & $\begin{array}{l}\text { Level of } \\
\text { Significance }\end{array}$ \\
\hline $\begin{array}{l}\text { Working } \\
\text { women }\end{array}$ & 30 & 20.33 & 2.96 & 2.46 & \multirow{2}{*}{0.05} \\
\cline { 1 - 2 } $\begin{array}{l}\text { Non } \\
\text { working } \\
\text { women }\end{array}$ & 30 & 20.47 & 3.95 & & \\
\hline
\end{tabular}

$* * \mathbf{p}<\mathbf{0 . 0 5}$

\section{DISCUSSION:}

Table: 1

The outcome of the present study clearly indicates that there is a lot of difference between the working and non working women in terms of mental health. The mean of working women is 184.23 and non working women are 175.73. It is clear that the health level of non working women is less as compared to working women. On the basis of this result we can say that because of heaps of mental pressure with regard to bringing up the children, maintaining pleasant relationship with in laws and their relatives and above all having good compatibility with the husband, extreme isolation are some the factors insofar as mental health is concerned and it is evident from the result that non working women suffer more as compared to working woman.

According to the' $t$ ' test the numeric value that we get is 2.13 which are significant etc. 0.05 levels. Therefore the hypothesis that there is no difference between working and nonworking women in mental health stands rejected.

\section{Table: 2}

The outcome of the present study clearly indicates that there is a difference between the working and non working women in terms of marital adjustment. The mean of working women is 20.33 and non working women are 22.47. It is clear that the adjustment level of working women is less as compared to non working women. It is evident therefore that the responsibilities like done social, with regard to child care, cordial relationship with in laws and
(C) 2014 www.ijip.in
July-September 2014
$68 \mid \mathrm{P}$ a g e 


\section{The International Journal of Indian Psychology: Volume: 01 | Issue: 04 | ISSN 2348-5396}

their relatives and satisfactory relationship with the husband etc are the factors that we very important in marital adjustment. No matter how responsible a woman is, her marital life suffers a lat because of social indignation.

According to the t' test the numeric value that we get is 2.46 which is significant at 0.05 level Therefore hypothesis that there is no difference between working and non workingwomen in marital adjustment stands rejected.

In modern time price rise has created multiple problems and as a result the financial responsibilities are on both, wife and husband we can say therefore that there are a lot of problems that arise with regard to adjustment which later on results into adjustment disorder. Every individual therefore has to be aware enough about the mental health problems that may arise. If proper precautions are taken I am sure there will be significant decrease in the issue of marital adjustment and mental health.

\section{CONCLUSION:}

There is significance difference between Working and Non-Working Women in Mental Health and Marital Adjustment. Therefore the Hypothesis here stands not accepted.

\section{REFERENCES:}

1. Nelson, D. L. and Bruke R. J. (2000). Women Executive Health, Stress and Success. The Academy of Management Executive, 14, 107-21.

2. Nolen-Hoeksena, S. and Girgus I. S. (1994). The emergence of gender differences in Depression During adolescences .Psychological Bulletin, 115, 423-43.

3. Pandya M. and Zala K. (2009). Saurashtra Psychological Association, Abstract Suchitra Publication, Rajkot, p. 30-33.

4. Pillai S. and Sen, A. K. (1998). Work and Family: A Psychosocial study of dual career women. Indian Journal of Clinical Psychology, 25, p. 165-169.

5. Whilhelm, K. and Roy, K. (2003). Gender differences in Depression Risk and Coping Factor in A clinical Sample. Act Psychiatric a Scandianic. 106, 45-531. 